\title{
Potential Development of Digital Environmental Surveillance System in Dengue Control: A Qualitative Study
}

\author{
Sang Purnama ${ }^{1 *} \mathbb{D}$, Dewi Susanna ${ }^{2} \mathbb{D}$, Umar Fachmi Achmadi $^{2}$, Tri Krianto $^{3} \mathbb{D}$, Tris Eryando $^{4}$ \\ ${ }^{1}$ Doctoral Study Program, Faculty of Public Health, University of Indonesia, Jakarta, Indonesia; ${ }^{2}$ Department of Environmental \\ Health, Faculty of Public Health, University of Indonesia, Jakarta, Indonesia; ${ }^{3}$ Department of Education and Behavioral Science, \\ Faculty of Public Health, University of Indonesia, Jakarta, Indonesia; ${ }^{4}$ Department of Biostatistics, Faculty of Public Health, \\ University of Indonesia, Jakarta, Indonesia
}

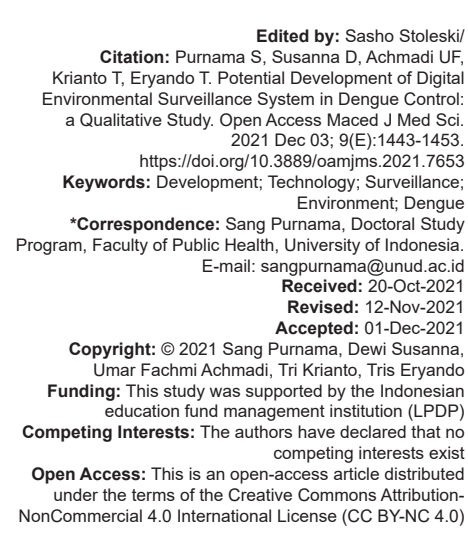

Introduction

Dengue is a global disease, especially in tropical climates, and it is reported that around 390 million infections occur annually [1]. Since 1968, Indonesia has become an endemic area of dengue hemorrhagic fever (DHF), and the incidence continues to increase from children to older age groups [2]. The spread is mainly by Aedes aegypti and Aedes albopictus mosquitoes [3], [4]. The existence of four circulating serotypes of the virus increases the incidence rate of the infection [5]. Meanwhile, Bali is a tourism area with a high incidence of dengue and the level of tourist mobility can become disease associated with travelers [6].

Epidemiological and entomological data should be collected in dengue infection surveillance [7], [8], [9], [10] by conducting home visits to record larva density per region and case. Environmental factors also affect the density of larvae and mosquitoes such as the number of potential breeding places [11], [12], [13], [14]. COVID-19 has spread to various countries and caused WHO to issue health protocols for physical distancing and not welcoming guests [15], [16]. This complicates the setting up of the dengue infection surveillance system, which is done directly through home visits. In addition, digital technology is needed to observe the density of larvae and the dengue infection in the region [17].

The use of a manual system to perform a paper-based surveillance system requires re-recording and potential data bias. Different obstacles were also found when writing reports, not being integrated, large piles of paper, and potentially lost and difficult to obtain. Therefore, digital technology is needed to conduct continuous and systematic surveillance.

An early detection system for dengue outbreaks needs to be developed [18], and this system is useful for collecting case reports, mapping high-risk areas, potential outbreaks, and rapid control measures. Furthermore, the Indonesian government promotes digital interventions to control various diseases. 
Digital technology was developed by several countries for dengue control such as smartphone geospatial apps [19], mobile phones for the prevention and control of arboviral diseases [20], Epihack Sri Lanka [21], and Cell Phone-Based System (Chaak) [22].

The role of digital technology in dengue control is very necessary at this time, especially during the COVID-19 pandemic. Bali as an endemic tourism area should develop integrated environmental information system technology in dengue control. This study aims to determine the obstacles in the implementation of dengue infection control programs and the potential for developing a digital environmental surveillance system in dengue control.

\section{Methods}

An exploratory qualitative approach was conducted using in-depth interviews and focuses group discussions with relevant stakeholders. Furthermore, interviews were conducted using Webex and Zoom applications to reduce the risk of direct contact during the COVID-19 pandemic, and the activities will be held in 2021. Denpasar City is one of the endemic areas for DHF in Bali Province. It is located at an altitude of 0-75 $\mathrm{m}$ above sea level, located at a position of $8^{\circ} 35^{\prime} 31^{\prime \prime}$ to $8^{\circ} 44^{\prime} 49^{\prime \prime}$ south latitude and $115^{\circ} 00^{\prime} 23^{\prime \prime}$ to $115^{\circ} 16^{\prime} 27^{\prime \prime}$ east longitude. The area is $127.78 \mathrm{~km}^{2}$ and the population of the city is 962,900 people [23].

Informants were selected according to the needs of the study, and the inclusion criteria are over 17 years old, have lived in the Denpasar area for more than 1 year, and can communicate. Furthermore, they have received an explanation about this study and agreed to conduct interviews. Selected informants are those with knowledge and experience in meeting the data requirements of this study. An in-depth interview was conducted with 14 key respondents as policymakers in their area as well as four groups for focus group discussions (FGD). The informants for in-depth interview was the Head of the Bali Provincial Health Office, The Head of the Denpasar City Health Department, four Head of the Community Health Center, two hospital surveillance officers, one Head of the infectious disease control department, and five health center surveillance officer. Meanwhile, the FGD consisted of two groups of village volunteers (jumantik), and community leaders to explore the information needed and validate the information obtained (Table 1). This is also done to triangulate data based on themes found through group discussions. The exploration was conducted on the constraints of program implementation, entomological surveillance, epidemiological surveillance flows, the potential for digital technology development, human resource support, facility support, financial support, and policy support (Table 2). The interviews were recorded using the Webex application tool following the decree of the World Health Organization concerning physical and social distancing.

Table 1: List of key informants by strata

\begin{tabular}{lll}
\hline Strata & Abbreviation & $\begin{array}{l}\text { Number of key } \\
\text { informants }\end{array}$ \\
\hline Head of the city health department & KD & 1 \\
Head of the infectious disease, city health office & KPL & 1 \\
Head of dengue program, city health office & KDBD & 1 \\
Head of DHF program & KPD & 1 \\
Head of public health center & KP & 4 \\
Head of surveillance PHC & KS & 2 \\
Jumantik Coordinator & JK & 4 \\
FGD jumantik & FGD-J & 2 \\
FGD village head & FGD-H & 2 \\
\hline FGD: Focus group discussion, DHF: Dengue hemorrhagic fever. &
\end{tabular}

FGD: Focus group discussion, DHF: Dengue hemorragic fever.

Table 2: Definition of theme

\begin{tabular}{ll}
\hline Theme & Definition \\
\hline Identification of surveillance & Find ways to collect analysis data, interpret \\
system & dengue cases and larvae density \\
Program barriers & Several factors that hinder the activities of \\
& dengue control programs \\
Identify digital system & Assessing opportunities in creating a digital \\
development opportunities & dengue control system \\
Challenges of digital system & Identify potential challenges in implementing \\
intervention & digital surveillance systems \\
\hline
\end{tabular}

This study uses thematic content analysis with 6 steps according to Braun and Clarke [24], namely: (1) introduction and deepening of data, (2) coding according to the transcribed data, (3) understanding the relationship of the code made with the study theme, (4) paying attention to each visited theme that has reflected the data set, (5) defining the themes created and analyzing the data contained in each theme, (6) making a report on the analysis of the results. The advantage of qualitative study is that the data collected and coded are valid and reliable [25].

After the interview was completed, a discussion with the team was conducted about the interesting findings. The recordings are transcribed verbatim, and a translator was used to ensure the reliability of the data. Detailed reading was conducted to familiarize with the data and identify the initial code for the purpose. Furthermore, the key themes and interesting elements were comprehensively identified. The results of categories and themes with existing data from references were compared. Triangulation was then used to reduce the effect of bias through the interview method and direct observation of field conditions. The various existing reference sources were then confirmed to ensure data validation.

\section{Ethical consideration}

This study has been approved by the ethics committee of the Faculty of Public Health, University of Indonesia (Ket-416/UN2.F10. D11/PPM.00.02/2021). Before data collection, informants had received information about their goals, risks, and rights. A written consent form was given to the informant before the interview. All information from participants is confidential and for this study only. All information collected in the 
form of recordings and transcripts is stored securely by the researcher.

\section{Results}

\section{Identification of surveillance system}

\section{Epidemiological surveillance}

Epidemiological surveillance of dengue infection is a systematic and continuous activity of collecting data, analyzing, and interpreting dengue infection to plan, implement and evaluate the disease control programs. Sources of data were obtained from public health centers (Puskesmas) and hospitals. Data collected on case findings of dengue infection consisted of name, age, gender, address, date of hospital admission, clinical symptoms, and laboratory results. The hospital makes an early alert report (KDRS) $1 \times 24 \mathrm{~h}$ after a positive case of DHF is found before reporting to the Department of Health.

Data from the hospital regarding the patient's identity and the positive status of DHF are reported to the Department of Health. The reports are forwarded to the Puskesmas, then to the surveillance officer to conduct an epidemiological investigation (EI) at the case house. This investigation reports the number of houses that were positive for larvae, where about 20 houses were reported to have dengue fever. When larvae are found and there are more than 3 people with fever without a known cause, it is reported as a vulnerable area. The data is recorded and forwarded to the health office to take action of spraying with larvicides or not. This method is only useful for killing adult mosquitoes, while the larvae will continue to grow.

"For the flow of dengue fever cases, we usually have a surveillance group with a hospital. Then, from the hospital surveillance that reports or the head of the environment can also report to the jumantik." (KDBD)

"Hospitals are required to send data about these patients to the health department. The health office, which will continue the data sent by the hospital to the puskesmas and puskesmas sees and selects the working area from the patient's address (JK4)."

Reporting of dengue cases can also be actively conducted through the head of the local environment. When there is a case report from the community, it will be confirmed again with data from the hospital and the health office. Then the surveillance team will clarify the real conditions that exist and collect data on cases, people with a fever around the area, and the presence of mosquito larvae.

"For the flow of dengue fever cases here, there is usually a surveillance group with a hospital.
Furthermore, from hospital surveillance that reports to their group or no report, it can be from the head of the environment that knows first. Furthermore, they can also report to their jumantik like that' (JK 2)

"For the epidemiological investigation, the whole area has to be directly investigated. The sources of the cases and the larva was found (JK1)"

Data collection by the District Health Office is both passive and active, and the collection was conducted by waiting for reports from Puskesmas and hospitals through telephone. It can also performed by direct supervision of early warning reports and periodic larva inspection reports.

Currently, manual forms of reporting are adopted based on reports sent by the Department of Health to the Puskesmas for Els. Reported cases of DHF will be carried out by an El by the Puskesmas surveillance officer together with jumantik. The reporting frequency is daily, weekly, and monthly. Daily reports related to cases and larvae density were collected from the results of Els. Furthermore, the results are recapitulated and reported to the health department. The monthly report is an accumulation of data on cases of dengue infection and the number of larvae density in each village.

The indicators used for DHF are incident rate, case fatality rate (CFR), house index ( $\mathrm{HI})$. Meanwhile, the incidence rate is the rate of new cases of a condition observed in a given period in the exposed population. Incidence rate used the standard $51 / 100,000$ population, and the CFR is the proportion of deaths in a given population from the total number of people that are sick or have symptoms of a disease (Standard CFR is $<1 \%)$. $\mathrm{HI}$ is the percentage of larval positive houses per all houses inspected (5\%) [26].

\section{Entomological surveillance}

Entomological surveillance is an activity used to obtain data continuously and systematically which is conducted concerning the vector density in the area. The data collected include the indicators of larva-free numbers, $\mathrm{HI}$, container index, Breteau index, number of water reservoirs in and outside the house. These data can be analyzed and considered in making decisions in dengue vector control.

Entomological surveillance is conducted routinely by monitoring volunteers (jumantik) and collecting larva density data in every house of residents visited every day as many as 20 houses. The data recorded were the number of larvae positive houses, the number of larvae positive containers, the number of containers inside and outside the house, the number that was given larvicide. Furthermore, the data is collected every day at the Puskesmas and reported to the City Health Office every month (Figure 1). 


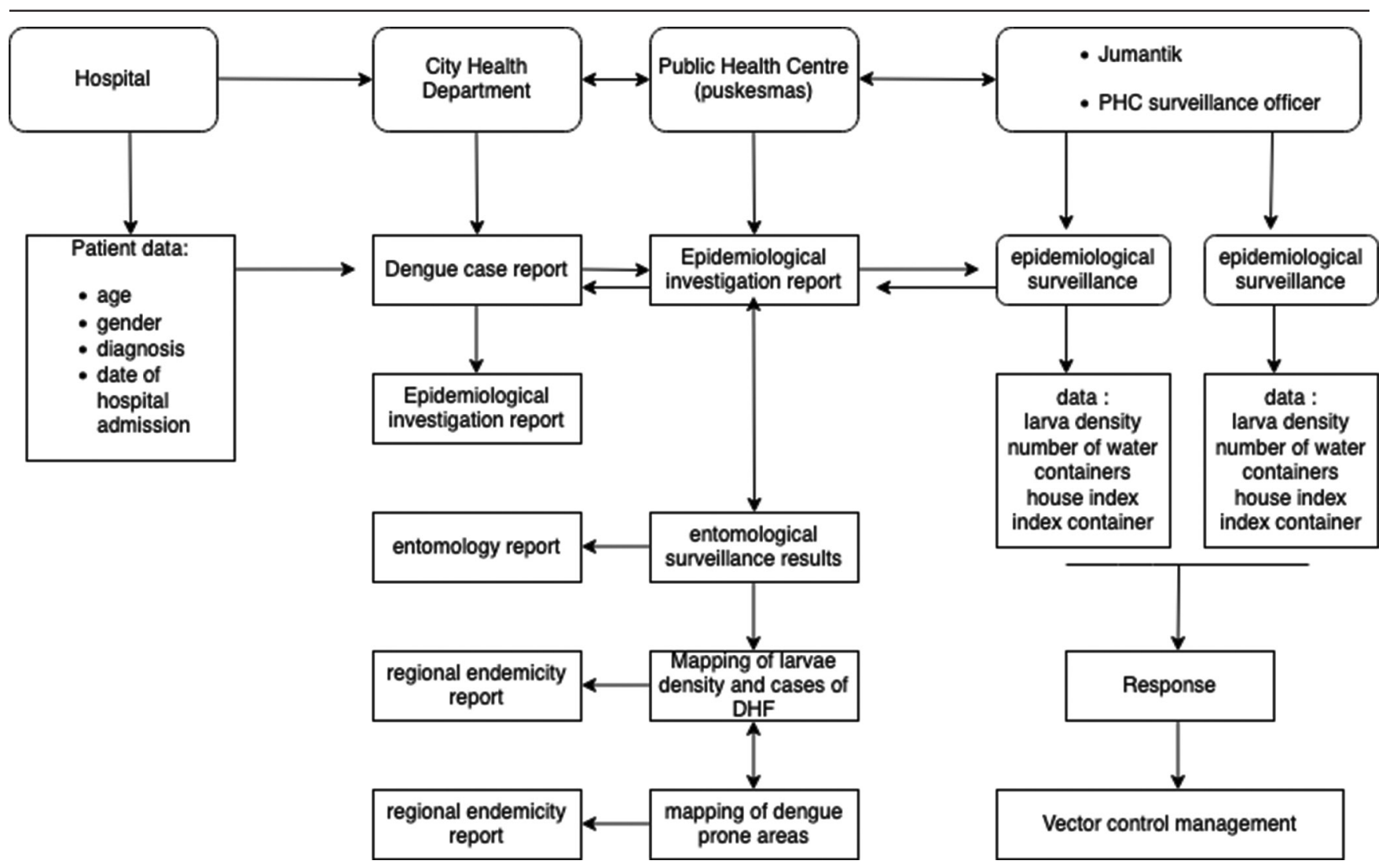

Figure 1 : Data flow of entomological and epidemiological surveillance systems

In Denpasar City, there are larvae monitoring volunteers (jumantik) in each Banjar (the division of territory under the village). Jumantik is a volunteer from the direct community recruited by the health office to conduct entomological surveillance. It has the task of conducting larval checks on residents' homes every day to record larva density figures, provide education to the public, conduct larva eradication activities, and put stickers on homes that were positive for larvae.

". Jumantik made a home visit by bringing a form or a blank. Furthermore, they fill out the sheet and they visit at least 20 households per day." (KDBD).

"In the field, the water reservoirs around the residents' homes, such as bathroom water reservoirs, water pots, and dispensers were checked. Furthermore, counseling was also provided concerning dengue fever." (FGD-J2)

During the COVID-19 pandemic, there are policies to conduct social and physical distancing. However, for jumantik activities, larval checks will still be conducted by complying with health protocols such as using masks, maintaining distance, wearing face shields and hand sanitizers. This is because it is the responsibility of the officers to eradicate mosquito breeding sites routinely by the community once a week.

".even in the current situation of the COVID-19 pandemic, we still go to the field to monitor larvae but with strict health protocols. Therefore, jumantik has been facilitated with masks, face shields, and gloves." (JK 4)

Hospitals that find cases of dengue infection report the incidence of DHF with patient identity data through hospital early alert reporting (KDRS) within 1 $\times 24 \mathrm{~h}$ to the City Health Department. DHF case data from the City Health Department was followed up with the Puskesmas. Meanwhile, the Puskesmas carried out an El by sending surveillance officers. The results of the investigation are reported to take control measures such as spraying insecticides from the City Health Department. Jumantik routinely reports entomological surveillance (larval density) to the Puskesmas, and the data is recorded and reported to the City Health Department every month.

\section{Program barriers}

\section{Performance measurement}

Currently, the manual attendance system is still used, and measuring the performance of jumantik becomes difficult to conduct. The data are not realtime entering from jumantik to the coordinator and public health center. Therefore, it is not sent on time as needed and there can be bias during data collection, recapitulation, and delivery. For this reason, a fast and precise system is needed to collect data in real-time.

"Jumantik performance can only be seen from attendance manually, also its accuracy in 
obtaining results in the field is seen. Therefore, it is a bit difficult to see jumantik's performance outside real-time". (KD).

"...in the morning we will gather at the banjar and attend to each other. Then the monitoring of the area and the task of the coordinator are also there to monitor the performance of the jumantik... (JK1)"

The current manual system is also difficult to control the level of field visits from jumantik and this can lead to bias in the reported data with the actual results. A valid coordinate-based data collection system is required to determine the location of officers, cases, and larvae.

"It is difficult for us to monitor because there is a lot of jumantik, and there are 431 in total for the whole city of Denpasar. Therefore, it is very difficult to monitor everything" (KDBD).

\section{Information speed barrier}

Speed of information in making policy is needed, and the manual system of information is slower to obtain. The information still needs to be recorded by the officer, coordinator, and the city health department. Repetitive recording systems like this take time and risk data bias.

"This will hamper the program to obtain information faster and the larvae monitoring in the field" (KD)

"I think it can help, because the information can be sent to the office more quickly" (JK1)

\section{Case surveillance barriers}

Reports of dengue cases from hospitals, health offices, and community health centers are often found with different home addresses. This confused the surveillance officers in the field because the address did not match and the case was not found. Furthermore, the high level of population mobility often changes places of residence. The staff's working hours, which are only 8-12 h, often clash with that of the community. Therefore, residents' houses are often empty and cannot be visited especially in urban areas.

"There are often cases like that. For example, it is written on X's village id card but he lives in $Y$, infected with dengue. We enter village $Y$ or according to the id card, namely $X$, and sometimes like this, he goes to village $Y$, maybe he works or opens a shop. Then that night he returned to village $X$, his daily life was like that." (FGD-J 1)

"When we are in the field, the difficulty is if there are empty houses and the mobility of the population here is high. Therefore, the house is indeed occupied but we can't find it because of time constraints." (JK 2)

For the vacant house, coordination is conducted with the head of the local neighborhood to contact and educate the owner. The jumantik officer will make a repeat visit and record in the next period. During the current COVID-19 pandemic, many house owners returned to the village because they are no longer working in the city. This also needs attention, considering that there is a water reservoir in the house with the potential to become a breeding sites for mosquitoes.

"We also coordinate with the Lurah, the village head and the neighborhood head to inform us that we have not been allowed to enter. Furthermore, the head of the neighborhood is also expected to inform the residents." FGD-J1

\section{Barriers to data collection systems}

This manual system causes officers to use many reporting forms, and the number of areas being monitored is relatively wide. Therefore, many forms of entomological surveillance results should be recapitulated every day, and can also be a bias when re-recording data. The use of hardcopy forms also causes the rest of the documents to pile up in the room and the warehouse.

\begin{abstract}
"At the end of the year there are many results of jumantik monitoring. The results of monitoring forms at home or in public places show many epidemiological investigation forms." (KS1)

".because every day the report uses paper and manually written there is the name of the head of the family, the address and also the number of water reservoirs with the presence of larvae" (JK1)
\end{abstract}

\section{Human resource barriers}

The number of human resources at the Puskesmas is limited in number compared to the current program, and they are often held in multiple positions and across programs. The number of jumantik compared to the house that should be visited every day also needs to be reviewed because it is also burdened with El activities. One Puskesmas area should take care of more than 10 villages with large populations. Therefore, optimal human resource management is needed.

"There are quite a lot of obstacles but the human resource is clear from internal HR. Furthermore, the DHF program is still held in concurrent positions." (KP1)

"If it's now, it's because our strength is lacking, so maybe it's a little less. However, it is impossible to monitor all banjar" (JK3) 


\section{Budget and infrastructure constraints}

The budget for controlling infectious diseases including dengue is currently limited in number because more budget policies are diverted to control the COVID-19 pandemic. Therefore, larvicides, brochures, surveillance forms, and activities supporting facilities are limited in number.

"Currently the budget is used for controlling COVID-19 to limit the number of facilities and infrastructure for activities in the field such as surveillance forms, brochures, larvacides, flashlights." (KPL)

"The implementation of programs such as larvicidation with abate is limited and also for fogging because some of the budgets have been diverted for handling COVID-19" (KS2).

\section{Identify system development opportunities}

Manually conducted data collection takes time and it has a high potential of errors when reporting. It causes administrative costs since jumantik performance measurement is difficult to conduct based on attendance and photos of activities. The speed of data reporting is limited, and the case data is not mapped based on coordinates since a large file storage area is required.

Digital system development is required to measure jumantik performance, and the City Health Office can monitor the performance of field officers. Furthermore, reports can also be sent with softcopy since they are easier to access and collect without the need to pile up paper in the warehouse.

"I think it is useful because the application can ensure that the jumantik is indeed a field visit. Then also save later on paper" (KS 2)

"I think it can help because the information can be reported to the health department more quickly." (JK1)

Digital applications are highly expected by the city health office and centers. The digital system will facilitate the work of field officers to produce more disciplined and evidence-based work. Leaders have access to surveillance data, and they can make decisions.

"This application is really what we want and indeed we have always dreamed of having it. Following the existence, talking is now supported with the system. That's why we welcome and we are very grateful" (KD)

When itcomesto Epidemiological Investigations $(P E)$, I agree to link directly to the department because we ask the health department for fogging. When it is directly linked it is easier to avoid sending the report, and the policy can be easily implemented. (FGD-J2)

\section{Coordinate points help to map}

Geotagging data collection of house coordinates for dengue cases and houses are positive for larvae, and this data is useful in mapping the areas prone to dengue infection. The results of mapping high, medium, and low-risk areas can help in prioritizing areas categorized as vulnerable to control dengue infection quickly and appropriately.

".Since everything is conducted through the digital era, it is better to determine the highest area based on mapping" (KPD).

"This is good, especially nowadays since the era of technology is better. Moreover, the GPS method was used to make a report and check the quality of data..." (KPL)

This application is expected to be integrated into the results of epidemiological and entomological surveillance for vulnerable areas. It is reported in parallel to the Puskesmas, the City, and Provincial Health Offices. Therefore, decision-makers can make appropriate and fast policies by the results of the data reported.

"Oh yeah, I think that's great. We can see if the case spreads to the surroundings or not. Furthermore, there is indeed an application to record the coordinates and has been directly connected to the head of the city's health department. The health office, for example, asked for data not to have to check again with the jumantik coordinator to see the data in the application." (JK 4)

\section{Digital educational videos}

This application is expected to intervene in the community and promote activities for eradicating mosquito breeding sites. Therefore, health promotion media should be made in the form of educational videos. Through educational videos that can be accessed openly on applications or websites, the public can access them easily. Direct door-to-door counseling during the COVID-19 pandemic can be avoided because it is risky. Furthermore, digital educational videos are more appropriate, especially in urban areas. people

".It reduces contact because giving direct counseling takes time, and in an urban area, it is rather busy." (JK 2)

"When there is a video, the community has a visual to increase community participation and can be packaged attractively" (KS1)

Infrastructure also supports this intervention since every member of the family has a mobile phone connected to the internet. They prefer to watch videos with moving pictures rather than reading brochures. 
Furthermore, children and adults are more interested in watching videos because they are more interesting. Children can also conduct mosquito eradication activities in their schools and homes.

"In my opinion, it is more useful because every family member in the house can watch it. Furthermore, almost every family member at home has a cell phone and they also prefer to watch it with moving pictures than reading....". (JK 4)

Digital technology innovation is required during the current COVID-19 pandemic, and people are used to using the WhatsApp application to communicate. Furthermore, Whatsapp groups can also be created in each region through educational videos. Jumantik has also used WhatsApp to send data and disseminate information such as public brochures.

"ee... this video is useful. ee. especially in the COVID-19 era, where information technology is very useful. People already have cellphones containing the WhatsApp application." (KPL)

\section{Community participation}

Community participation in eradicating mosquito breeding sites is very necessary, and vector control activities are everyone's responsibility. The community can actively participate in recording, reporting, and controlling vectors. Jumantik helps obtain data, and the community is expected to participate in this activity.

"...Jumantik's job is also to educate the public, and sustainability of the activity is the responsibility of the homeowner. There is also a shared responsibility for vector control (PSN)." (KS 1)

".maybe many have started to replace their water reservoirs, and in the past, they still used tubs because they found it difficult to clean (FGD-H1)"

\section{Support from stakeholders}

Support from stakeholders in the implementation of a digital environmental surveillance system can control DHF. The regional head supports surveillance activities, and every village and the regional head has social media, where information can be sent directly when there is a case of dengue infection. Information on the results of EI data can be sent to the village and local regional heads in each region. This coordination can be integrated and reported to the city health office. Therefore, the decision to conduct fumigation with insecticides can be made.

“....Every activity conducted was shared with the village head. When there are larvae or cases, we will immediately share them and the head of the village will go directly to the homes of sick people" (FGD-J1).

\section{Model of the integrated environmental surveillance system for dengue control (SILIRA)}

Integrated digital environmental surveillance system (SILIRA) and DHF case reports from hospitals, clinics, health centers that are diagnosed positively with DHF (Hospital-based surveillance) are reported directly to the city health office. Furthermore, case reports can also come from the community (Community based surveillance), and those from the public are re-confirmed from reports received by the city health office (Table 3 ).

Epidemiological surveillance: through the SILIRA application, Els can use digital questionnaires with coordinates to map case houses. Real-time data is entered into the server of the Puskesmas and the City Health Office. This data is analyzed in the system and displayed in the form of percentages and case density maps. Furthermore, the data can also be accessed in real-time and online by all stakeholders (Figure 2).

Entomological surveillance: through the SILIRA application, jumantik can collect online digital data about larva density with coordinates and pictures of containers. The data can be displayed in real-time,

Table 3: Identification of constraints and solutions for the digital approach

\begin{tabular}{|c|c|c|}
\hline Variable & Program constraints & Digital approach solution \\
\hline Performance measurement & $\begin{array}{l}\text { Performance measurement still uses attendance manually, and it is difficult } \\
\text { to monitor the actual jumantik visit rate. The data are not sent on time as } \\
\text { needed and there can be bias when the collection does not match the day } \\
\text { and date. Therefore, a system that can quickly and precisely collect data is } \\
\text { required }\end{array}$ & $\begin{array}{l}\text { Jumantik performance can be monitored in real-time because the visited } \\
\text { houses will be recorded in the coordinates. Furthermore, reports can be } \\
\text { directly received by the health office, Puskesmas without the need for } \\
\text { recapitulation. This is to reduce data bias }\end{array}$ \\
\hline Information speed & $\begin{array}{l}\text { Surveillance results take time because they need to be recorded by field } \\
\text { officers, coordinators, and the health office }\end{array}$ & $\begin{array}{l}\text { The results of surveillance activities in the field can be directly and in } \\
\text { real-time into the Puskesmas and health offices }\end{array}$ \\
\hline Case surveillance constraints & $\begin{array}{l}\text { Reports of dengue cases from the Health Office to the Puskesmas are often } \\
\text { found at different addresses }\end{array}$ & $\begin{array}{l}\text { Reports from the hospital can be directly confirmed by the coordinates } \\
\text { of the house, thereby reducing the risk of data errors }\end{array}$ \\
\hline Data collection system constraints & $\begin{array}{l}\text { This manual system causes the use of many reporting forms, and can also } \\
\text { be a data bias when re-recording data }\end{array}$ & $\begin{array}{l}\text { The data does not need to be recorded repeatedly because it will go } \\
\text { directly to the server of the health service and Puskesmas }\end{array}$ \\
\hline Human resource constraints & $\begin{array}{l}\text { The number of human resources at the Puskesmas is limited in number } \\
\text { compared to the current program. Therefore, they are often held in multiple } \\
\text { positions and across programs. The number of jumantik compared to the } \\
\text { house that should be visited every day also needs to be reviewed }\end{array}$ & $\begin{array}{l}\text { Fewer human resources are needed when data collection activities can } \\
\text { be conducted by the community directly online. The community can } \\
\text { actively participate independently in surveillance activities }\end{array}$ \\
\hline Budget and facility constraints & $\begin{array}{l}\text { The budget was diverted to control the COVID-19 pandemic to limit the } \\
\text { provision of facilities such as brochures, larvacides, surveillance forms, and } \\
\text { supporting facilities }\end{array}$ & $\begin{array}{l}\text { The budget for facilities such as paper, brochures, and surveillance staff } \\
\text { can be reduced because the public can access information online }\end{array}$ \\
\hline File storage & $\begin{array}{l}\text { Files in the form of documentation data papers pile up in warehouses, take } \\
\text { up space, and are difficult to find data on }\end{array}$ & $\begin{array}{l}\text { Files can be in the form of soft copies stored on a computer safely, easy } \\
\text { to find, and easy to move }\end{array}$ \\
\hline Mapping & $\begin{array}{l}\text { Case data is not made into a map of vulnerable areas. This is because the } \\
\text { risk areas are determined from the number of cases and larvae density }\end{array}$ & $\begin{array}{l}\text { Risk areas can be mapped according to the coordinates of case } \\
\text { occurrences and the number of larvae. Therefore, high, medium, and } \\
\text { low susceptibility areas are mapped }\end{array}$ \\
\hline
\end{tabular}


mapping larvae density and percentage to conduct interventions quickly in high-risk areas.

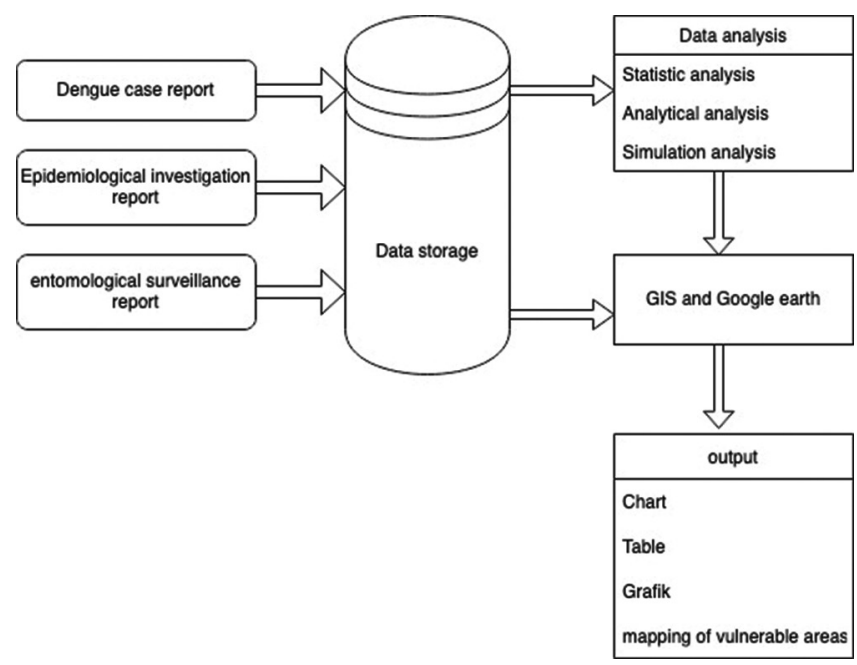

Figure 2: The flow of the reporting system with the SILIRA application

Digital educational videos are used to intervene in the community to increase their knowledge, attitudes, and actions in vector control. The community is educated to eradicate mosquito breeding sites at least once a week by draining water containers in their homes.

The results of epidemiological and entomological surveillance data are reported directly to the Puskesmas and the Health Office in an integrated manner. Meanwhile, the reports on surveillance results are also reported to the Provincial Health Office and the Ministry of Health (Figure 3).

\section{Challenges of digital system intervention}

Several potential challenges were identified in the implementation of the integrated dengue control digital surveillance system (SILIRA). Furthermore, WIFI access is required to input and send online reports through internet-based servers.

".oh, not all health centers have WIFI since the distance is far. Not all sub-health centers have WIFI, there are only health centers.....". (KP 2)

The potential for signal interference from the provider used can interfere with the reporting process. However, when internet access is not provided, then the report cannot be sent, and that is the weakness of the online system.

"...but I'm afraid now, it might be sophisticated. Sometimes events in the field are not expected with a problematic server and internet. Even though it is sophisticated when a lot of people

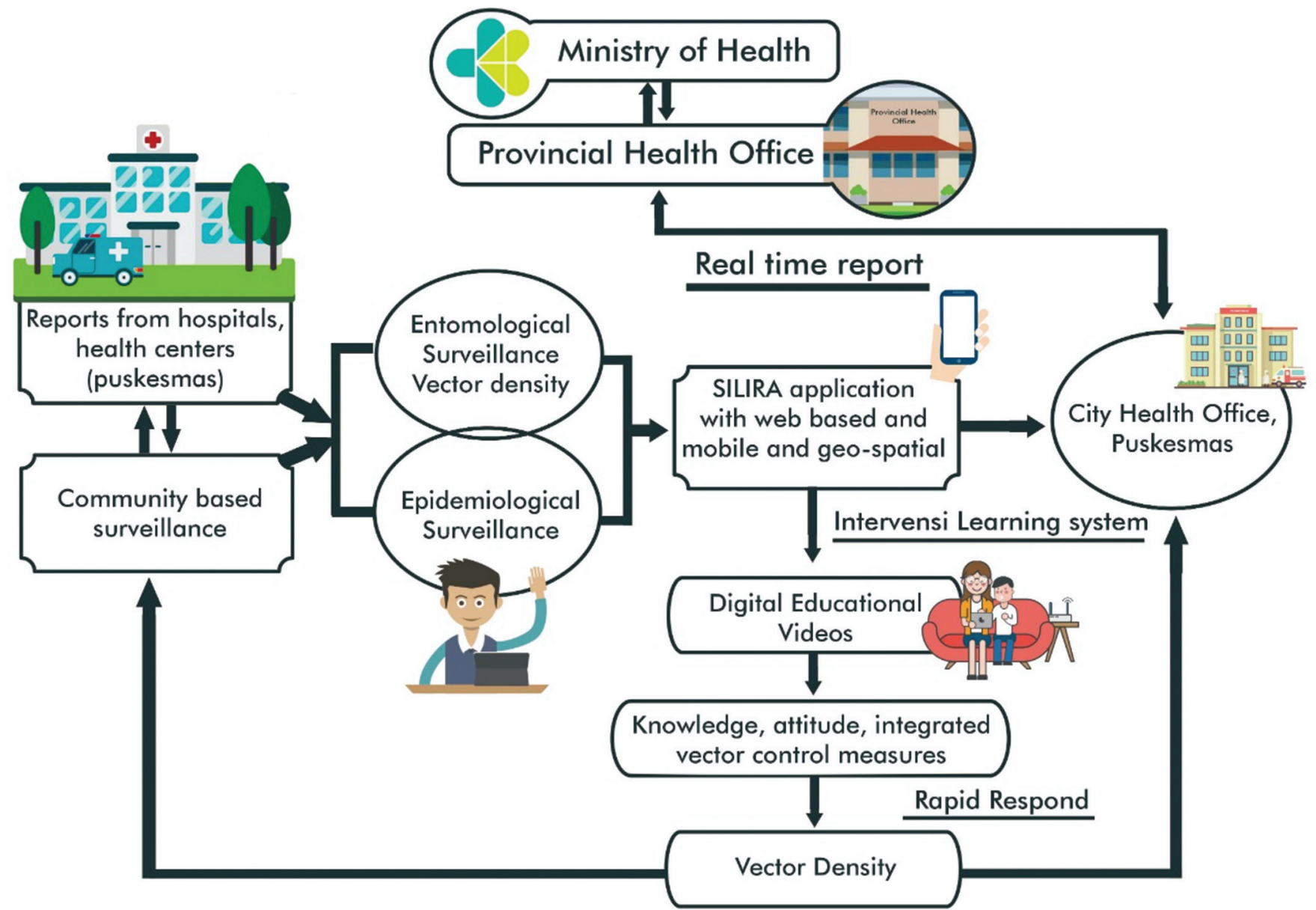

Figure 3: Model of an integrated environmental surveillance system for dengue control 
use the internet, it takes a long time to load due to error...... that's the problem." (FGD-J 2)

Small mobile devices do not support the use of an application such as small memory and android phone. The ability of officers to use new applications can also hamper them, such as not understanding the use of applications that are difficult to learn. The cost of purchasing a data package is also required for this activity.

"Mobile phones usually do not support, and can be made simpler, less complicated and expensive." (KP 2)

"Not all jumantik have an android mobile phone according to the data obtained from the CellPhone. This does not work because of the problem with buying data, and the manual method was then adopted." (FGD-J 1)

People without mobile phones and internet quota cannot access digital educational videos. All web and internet-based applications require supporting facilities, and this can be an obstacle to this intervention system.

"When you make videos, sometimes those that do not have Android are not aware ha. ha. there are problems like that" (KS 2)

The habits of the people served by the Jumantik were then asked to change, and independently recording based on digital technology is not easy.

"It familiarizes the community with vector control programs. However, it seems difficult to keep records because they are not used to recording daily activities...." (JK 2)

The COVID-19 pandemic requires people not to receive guests and keep their distance. It has an impact on surveillance activities in the houses of dengue-infected cases. Furthermore, it is necessary to observe the surrounding conditions whether there is a fever, larvae, or someone is infected with dengue. The action became difficult to conduct because there was resistance from the community when the surveillance officers visited.

"The arrival of officers was refused to prevent the transmission of COVID-19." (KPD)

\section{Discussion}

Epidemiological surveillance of dengue infection was conducted based on diagnosis reports from hospitals and public health centers. Meanwhile, mosquito and larval density data were obtained through entomological surveillance [27], [28]. The DHF surveillance system was perfomed by continuously collecting data on the infection and vector density to detect potential dengue outbreaks and control them quickly [10], [29], [30]. In this study, jumantik volunteers collected data on larva density daily using a paperbased manual method. The results showed weaknesses involving the speed of information, performance measurement, data bias, human resources, storage, and supporting facilities.

An integrated digital environmental surveillance system for dengue control has the potential to be developed. This system can solve manual problems such as collecting and transmitting data quickly, reducing data bias, reducing human resource requirements, reducing file storage space, and integrating data with all stakeholders. Digital systems help health services to fastly, easily, and simply collect data.

Several countries have implemented dengue digital surveillance system such as the Mozzipy application, collecting data and education [31], hospital-based surveillance [32], using Google Trends on the google search engine for early detection of dengue [33], a mobile-based system (called Chaak) for collecting data related to surveillance of adult mosquito stages [34], use of mobile phones to improve dengue prevention behavior [35], Epihack Sri Lanka [21], mapping system and Web-based for data analysis of DHF [36], [37].

Studies in some of these countries have only developed surveillance systems to conduct data collection and analysis. Furthermore, it is necessary to develop an integrated surveillance system to collect data, analyze and also intervene quickly and accurately. Through the development of an integrated digital surveillance system, it helps policy makers to carry out efforts to control dengue in their area. This system produces a mapping of dengue-prone areas so as to be able to prioritize dengue control programs.

Besides collecting integrated surveillance data, an educational video intervention was needed to increase community participation in vector control. The educational video is integrated with the data collection system for dengue infection and larva density. They are more interesting since visually moving images are compared to brochures, and video is one of the health promotion media to increase public knowledge [38].

There are several challenges in the application of digital surveillance systems. These include the lack of community participation, unequal access to the WIFI network, signal interference, not all officers have an android phone, the cost of data quota to run the application. Community participation in vector surveillance and control is still a serious challenge. The need for supporting facilities and infrastructure in supporting digital health interventions [39],[40]. 


\section{Conclusion}

This study indicates that paper-based manually performs repeated data entry and risks data bias. An integrated digital surveillance system can be developed to control dengue infection, and reduce the barriers to surveillance that is still paper-based. Furthermore, digital surveillance systems can speed up the process of data collection and transmission.

\section{Acknowledgments}

This study was supported by a Indonesian education fund management institution (LPDP). We would like to thank our field team, especially Bali Provincial Health Office, Denpasar City Health Office, Head of Public Health Center and field surveillance officers.

\section{References}

1. Bhatt S, Gething PW, Brady OJ, Messina JP, Farlow AW, Moyes $\mathrm{CL}$, et al. The global distribution and burden of dengue. Nature. 2013;496(7446):504-7. https://doi.org/10.1038/ nature12060

\section{PMid:23563266}

2. Karyanti MR, Uiterwaal CS, Kusriastuti R, Hadinegoro $S R$ Rovers MM, Heesterbeek $\mathrm{H}$, et al. The changing incidence of dengue haemorrhagic fever in Indonesia: A 45-year registrybased analysis. BMC Infect Dis. 2014;14(1):412. https://doi. org/10.1186/1471-2334-14-412

PMid:25064368

3. Ratnasari A, Jabal AR, Rahma N, Rahmi SN, Karmila M, Wahid I. The ecology of Aedes aegypti and Aedes albopictus larvae habitat in coastal areas of South Sulawesi, Indonesia. Biodiversitas. 2020;21(10):4648-54.

4. Ryan SJ, Carlson CJ, Mordecai EA, Johnson LR. Global expansion and redistribution of Aedes-Borne virus transmission risk with climate change. PLoS Negl Trop Dis. 2018;13(3):e0007213. https://doi.org/10.1371/journal. pntd. 0007213

PMid:30921321

5. Made Susila Utama I, Lukman N, Sukmawati DD, Alisjahbana B, Alam A, Murniati D, et al. Dengue viral infection in Indonesia: Epidemiology, diagnostic challenges, and mutations from an observational cohort study. PLoS Negl Trop Dis. 2019;13(10):e0007785. https://doi.org/10.1371/journal. pntd. 0007785

PMid:31634352

6. Masyeni S, Yohan B, Somia IK, Myint KSA, Sasmono RT. Dengue infection in international travellers visiting Bali, Indonesia. J Travel Med. 2018;25(1):tay061. https://doi.org/10.1093/jtm/ tay061

7. Cromwell EA, Stoddard ST, Barker CM, van Rie A, Messer WB, Meshnick SR, et al. The relationship between entomological indicators of Aedes aegypti abundance and dengue virus infection. PLoS Negl Trop Dis. 2017;11(3):e0005429. https:// doi.org/10.1371/journal.pntd.0005429

\section{PMid:28333938}

8. Madzlan F, Che N, Say C, Zakaria N. Breeding characteristics of Aedes mosquitoes in dengue risk area. Proc Soc Behav Sci. 2016;234:164-72.

9. Baak-Baak CM, Cigarroa-Toledo N, Pech-May A Cruz-Escalona GA, Cetina-Trejo RC, Tzuc-Dzul JC, et al. Entomological and virological surveillance for dengue virus in churches in merida, Mexico. Rev Inst Med Trop Sao Paulo. 2019;61:e9. PMid:30785563

10. Racloz V, Ramsey R, Tong S, Hu W. Surveillance of dengue fever virus: A review of epidemiological models and early warning systems. PLoS Negl Trop Dis. 2012;6(5):e1648. https:// doi.org/10.1371/journal.pntd.0001648 PMid:22629476

11. Buhler C, Winkler V, Runge-Ranzinger S, Boyce R, Horstick O Environmental methods for dengue vector control-a systematic review and meta-analysis. PLoS Negl Trop Dis. 2019;13(7):e0007420. https://doi.org/10.1371/journal. pntd.0007420

PMid:31295250

12. Siregar FA, Makmur T, Huda N. Key breeding place for dengue vectors and the impact of larvae density on dengue transmission in North Sumatera province, Indonesia. Asian J Epidemiol. 2017; 10(1):1-9.

13. Dom NC, Ahmad AH, Ismail R. Habitat characterization of Aedes sp. breeding in urban hotspot area. Proc Soc Behav Sci. 2013;85:100-9.

14. Getachew D, Tekie H, Gebre-Michael T, Balkew M, Mesfin A. Breeding sites of Aedes aegypti: Potential dengue vectors in Dire Dawa, East Ethiopia. Interdiscip Perspect Infect Dis. 2015;2015:706276. https://doi.org/10.1155/2015/706276 PMid:26435712

15. Jones NR, Qureshi ZU, Temple RJ, Larwood JP, Greenhalgh T, Bourouiba L. Two metres or one: What is the evidence for physical distancing in COVID-19? BMJ. 2020;370:m3223. https://doi.org/10.1136/bmj.m3223 PMid:32843355

16. Pratomo H. From social distancing to physical distancing: A challenge forevaluating public health intervention against COVID-19. Kesmas. 2020;15(2):60-3.

17. Yin MS, Bicout DJ, Haddawy P, Schöning J, Laosiritaworn $Y$, Sa-Angchai P. Added-value of mosquito vector breeding sites from street view images in the risk mapping of dengue incidence in Thailand. PLoS Negl Trop Dis. 2021;15(3):e0009122. https:// doi.org/10.1371/journal.pntd.0009122 PMid:33684130

18. Hussain-Alkhateeb L, Kroeger A, Olliaro P, Rocklöv J, Sewe MO, Tejeda G, et al. Early warning and response system (EWARS) for dengue outbreaks: Recent advancements towards widespread applications in critical settings. PLoS One. 2018;13(5):e0196811. https://doi.org/10.1371/journal. pone. 0196811 PMid:29727447

19. Babu AN, Niehaus E, Shah S, Unnithan C, Ramkumar PS, Shah J, et al. Smartphone geospatial apps for dengue control, prevention, prediction, and education: MOSapp, DISapp, and the mosquito perception index (MPI). Environ Monit Assess 2019;191 Suppl 2:393. https://doi.org/10.1007/ s10661-019-7425-0

PMid:31254076

20. Carrillo MA, Kroeger A, Sanchez RC, Monsalve SD, 
Ranzinger SR. The use of mobile phones for the prevention and control of arboviral diseases: A scoping review. BMC Public Health. 2020;21(1):110. https://doi.org/10.1186/ s12889-020-10126-4

PMid:33422034

21. Lwin MO, Sheldenkar A, Panchapakesan C, Ng JS, Lau J, Jayasundar K, et al. Epihack Sri Lanka: Development of a mobile surveillance tool for dengue fever. BMC Med Inform Decis Mak. 2019;19(1):111. https://doi.org/10.1186/s12911-019-0829-5 PMid:31196073

22. Lozano-Fuentes S, Wedyan F, Hernandez-Garcia E, Sadhu D, Ghosh S, Bieman JM, et al. Cell phone-based system (Chaak) for surveillance of immatures of dengue virus mosquito vectors. J Med Entomol. 2013;50(4):879-89. https://doi.org/10.1603/ me13008

PMid:23926788

23. Wikipedia, Denpasar; 2021. Available from: https://www.en. wikipedia.org/wiki/denpasar. [Last accessed on 2021 Aug 14.

24. Braun V, Clarke V. Using thematic analysis in psychology. Qual Res Psychol. 2006;3(2):77-101.

25. Elo $S$, Kääriäinen $M$, Kanste $O$, Pölkki T, Utriainen $K$,Kyngäs $H$. Qualitative content analysis. SAGE Open. 2014;4(1):1-10.

26. Kemenkes. Dengue Report in Indonesia. Jakarta: Kemenkes; 2020.

27. Balingit JC, Carvajal TM, Saito-Obata M, Gamboa M, Nicolasora AD, Sy AK, et al. Surveillance of dengue virus in individual Aedes aegypti mosquitoes collected concurrently with suspected human cases in Tarlac city, Philippines. Parasit Vectors. 2020;13(1):594. https://doi.org/10.1186/ s13071-020-04470-y PMid:33239063

28. Kosoltanapiwat $N$, Tongshoob J, Singkhaimuk $P$, Nitatsukprasert C, Davidson SA, Ponlawat A. Entomological surveillance for zika and dengue virus in Aedes mosquitoes: Implications for vector control in Thailand. Pathogens. 2020;9(6):442. https://doi.org/10.3390/pathogens9060442 PMid:32512828

29. Wartel TA, Prayitno A, Hadinegoro SRS, Capeding MR, Thisyakorn $\mathrm{U}$, Tran $\mathrm{NH}$, et al. Three decades of dengue surveillance in five highly endemic South East Asian countries: A descriptive review. Asia Pac J Public Health. 2017;29(1):7-16. https://doi.org/10.1177/1010539516675701 PMid:28198645

30. Beatty ME, Stone A, Fitzsimons DW, Hanna JN, Lam SK, Vong $\mathrm{S}$, et al. Best practices in dengue surveillance: A report from the asia-pacific and americas dengue prevention boards. PLoS Negl Trop Dis. 2010;4(11):e890. https://doi.org/10.1371/ journal.pntd.0000890 PMid:21103381

31. Herbuela VR, Karita T, Francisco ME, Watanabe K. An integrated mhealth app for dengue reporting and mapping, health communication, and behavior modification: Development and assessment of mozzify. JMIR Form Res. 2020;4(1):e16424. https://doi.org/10.2196/16424

PMid:31913128

32. Sulistyawati S, Nilsson M, Ekasari MP, Mulasari SA, Sukesi TW Padmawati RS, et al. Untapped potential: A qualitative study of a hospital-based dengue surveillance system. Am J Trop Med Hyg. 2020;103(1):120-31. https://doi.org/10.4269/ ajtmh.19-0719

PMid:32394883

33. Syamsuddin M, Fakhruddin M, Sahetapy-Engel JT, Soewono E. Causality analysis of Google trends and dengue incidence in Bandung, Indonesia with linkage of digital data modeling: Longitudinal observational study. J Med Internet Res. 2020;22(7):e17633. https://doi.org/10.2196/17633 PMid:32706682

34. Lozano-Fuentes S, Wedyan F, Hernandez-Garcia E, Sadhu D, Ghosh S, Bieman JM, et al. Cell phone-based system (chaak) for surveillance of immatures of dengue virus mosquito vectors. J Med Entomol. 2013;50(4):879-89. https://doi.org/10.1603/ me13008 PMid:23926788

35. Dammert AC, Galdo JC, Galdo V. Preventing dengue through mobile phones: Evidence from a field experiment in Peru. J Health Econ. 2014;35(1):147-61. https://doi.org/10.1016/j. jhealeco.2014.02.002 PMid:24681813

36. Zainab N, Tariq A, Saima S. Research article development of web-based GIS alert system for informing environmental risk of dengue infections in major cities of Pakistan naureen. Geosfera Indones. 2021;6(1):77-95.

37. Hernández-Ávila JE, Rodríguez MH, Santos-Luna $R$, Sánchez-Castañeda $\mathrm{V}$, Román-Pérez $\mathrm{S}$, Ríos-Salgado $\mathrm{VH}$, et al. Nation-Wide, Web-Based, geographic information system for the integrated surveillance and control of dengue fever in Mexico. PLoS One. 2013;8(8):e70231. https://doi.org/10.1371/ journal.pone.0070231 PMid:23936394

38. Hiremath P, Chakrabarty J, Sequira L. Video assisted education on knowledge and practices of house wives towards prevention of dengue fever at Gokak Taluk, Karnataka, India. Int J Health Promot Educ. 2020;58(5):259-67.

39. Tsheten T, Gray DJ, Clements ACA, Wangdi K. Epidemiology and challenges of dengue surveillance in the WHO South-East Asia Region. Trans R Soc Trop Med Hyg. 2021;115(6):583-99. https://doi.org/10.1093/trstmh/traa158 PMid:33410916

40. Nguyen-Tien $T$, Probandari A, Ahmad RA. Barriers to engaging communities in a dengue vector control program: An implementation research in an urban area in Hanoi city, Vietnam. Am J Trop Med Hyg. 2019;100(4):964-73. https://doi. org/10.4269/ajtmh.18-0411

PMid:30652660 